\title{
The effectiveness of a teacher professional learning programme: The perceptions and performance of mathematics teachers
}

\author{
Author: \\ Mdutshekelwa Ndlovu ${ }^{1}$ \\ Affiliation: \\ ${ }^{1}$ Centre for Pedagogy, Faculty \\ of Education, Stellenbosch \\ University, South Africa \\ Correspondence to: \\ Mdutshekelwa Ndlovu \\ Email: \\ mcn@sun.ac.za \\ Postal address: \\ Private Bag X1, Matieland \\ 7602, South Africa \\ Dates: \\ Received: 30 July 2013 \\ Accepted: 16 Nov. 2014 \\ Published: 12 Dec. 2014 \\ How to cite this article: \\ Ndlovu, M. (2014). \\ The effectiveness of a \\ teacher professional learning \\ programme: The perceptions \\ and performance of \\ mathematics teachers. \\ Pythagoras, 35(2), Art \#237, \\ 10 pages. http://dx.doi. \\ org/10.4102/pythagoras. \\ v35i2.237

\section{Copyright:} \\ (C) 2014. The Authors. \\ Licensee: AOSIS \\ OpenJournals. This work is \\ licensed under the Creative \\ Commons Attribution \\ License.
}

Read online:

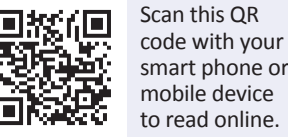

The purpose of this article is to report on an investigation of the perceptions and performance of mathematics teachers in a teacher professional learning (TPL) programme based on realistic mathematics education (RME) principles, which included a topic on transformations, undertaken by the researcher. Forty-seven Senior Phase (Grade 7-9) teachers took part in the mixed-methods study in which they answered a questionnaire with both closed and openended items. Fifty teachers took an achievement test at the end of the programme. The TPL programme used the RME approach in the design and delivery of mathematical tasks intended to enhance teachers' mathematical knowledge for teaching. The sessions were conducted in a manner that modelled one way in which RME principles can be adopted as a teacher professional development strategy. The significance of the study is that continuing TPL is acknowledged to contribute to improvement in teaching and learning to address the concern about unsatisfactory learner achievement in mathematics. The responses suggested that the majority of teachers experienced the sessions positively in relation to all but one of the six RME principles. The teachers reported that they took an active part both as individuals and in small groups and expressed their willingness to adopt the type of activities and materials for their classrooms, which is an essential first step in Guskey's first level of evaluation of a teacher TPL programme. The teachers' average performance in an achievement test at the end of the topic was $72 \%$ which was indicative of modest learning gains at Guskey's second level of TPL effectiveness.

\section{Introduction}

The poor performance of South African Grade 9 learners in the annual national assessments for mathematics in 2012 (Department of Basic Education, 2012) highlighted, amongst other factors, the need for quality teacher professional development or learning programmes. Guskey (2000, p. 16) defines professional development as processes and activities designed to enhance the professional knowledge, skills and attitudes of educators so that they might in turn improve the learning of students. The focus in this study was to make a contribution towards teachers' classroom practice in relation to Shulman's (1986) concepts of pedagogical content knowledge, subject matter knowledge and curriculum knowledge so that the teachers in turn could potentially improve the learning gains of their students. This study adopted Clarke and Hollingsworth's (2002) perspective of teacher change as growth or learning in which teachers are themselves learners who work in a learning community. When teachers come together for a contact professional development session they form a learning community.

Sowder (2007), however, notes that a lack of effective, job-embedded professional development for teachers can be observed in the field of continuing teacher professional learning (TPL) for practising teachers. Limited by time constraints, the impact of short-term lectures, meetings or workshops on teachers' behaviour and students' learning is limited (Hellmig, 2009). Roesken (2011) acknowledges that these constraints typify the traditional in-service programmes that simplify professional development to special events at some days during the school year. In their rushed nature, traditional approaches do not provide appropriate learning opportunities for teachers because they are designed in a hit-and-run fashion that compels them to focus more on outputs than on processes and outcomes. Traditional approaches have also been criticised for being change-oriented or deficit models that see teachers as in need of fixing thus depriving them of their own agency (Krainer, 2002, as cited by Roesken, 2011). However, contemporary views suggest that teachers cannot be developed (passively) or changed, but that they develop actively and what we need do is to provide opportunities for them to change and grow and to own the change processes (Day, 1999) in the hope that changes in practice could lead to changed student behaviours and possibly student learning (Guskey, 2002) and ultimately student achievement 
(outcomes) in national and international benchmark assessments. With fewer and fewer mathematics teachers being trained and more and more qualified mathematics teachers leaving the profession, TPL opportunities offer a reasonable prospect of addressing the imbalances in student achievement in the long term.

As part of a probable solution this study sought to articulate the design and implementation of a realistic mathematics education (RME)-informed TPL programme and to investigate, at Guskey's (2000) first (participants' reactions to training) and second (participants' learning) levels, the effectiveness of the programme in which the researcher was involved. The RME approach originated in the Netherlands and has been trialled in other countries. Examples include the Mathematics in Context high school textbook series in the United States (US) (Romberg, 2001), the Manchester Metropolitan University's RME pilot project in the United Kingdom (UL) (Dickinson \& Hough, 2012), the IndoMath project for the in-service education of junior secondary teachers in Indonesia (Hadi, 2002) and the Shanghai 'Teacher Action Education' programme in China (Cheung \& Huang, 2005). The Netherlands has previously performed well in international benchmark tests such as the Trends in International Mathematics and Science Study (TIMSS) and virtually all its mathematics textbooks are now RME based (Van den Heuvel-Panhuizen, 2010). The traditional approaches to in-service teacher education have probably not achieved their intended goals due to a myriad of factors. The significance of the study is that continuing TPL is acknowledged to contribute to improvement in teaching and learning (Goodall, Day, Lindsay, Muijs \& Harris, 2005), which tallies with the objectives of the intervention programme in this study conducted in the Western Cape in South Africa.

This study mainly sought to carry out Level 1 and Level 2 evaluations of the initial contact or workshop session. Guskey's (2000) first level evaluates the participants' reactions to whether the experiences were enjoyable and useful. This level is the most familiar and most widely used. The second level measures participants' learning in relation to gains in knowledge or skill.

\section{Conceptual framing of RME as a TPL approach \\ Rationale for using a learning theory as a framework for the design of TPL}

The curriculum materials used for mathematics in-service teacher education for the senior phase in this study were specifically designed to allow for a realistic mathematics education (RME) approach, which originated from the Freudenthal Institute in the Netherlands (Van den HeuvelPanhuizen, 2000). RME is a neo-constructivistapproach, which stresses that mathematics learning should, in Freudenthal's (1977) view, be connected to reality, stay close to children's experience and be relevant to society, in order to be of human value. The focal point should not be on mathematics as a value-free or context-free system, but on the activity or the process of mathematisation (Freudenthal, 1991). Treffers (1987) elaborates on mathematisation as consisting of both horizontal (solving problems set in a real-life situation, going from the world of life to the world of symbols) and vertical (reorganisation from the mathematical system itself, finding shortcuts and discovering connections between concepts and strategies and applying these strategies) dimensions.

Clarke and Hollingworth (2002) support models of professional development and growth that incorporate key features of contemporary learning theory; an RME approach is one such potential model. Contemporary views of staff development also promote constructivist approaches in the delivery of professional development programmes (Beck, Czemiak \& Lumpe, 2000) on grounds that for teachers to effectively adopt new teaching strategies they need to experience a professional development programme that builds their understanding of those new strategies through explicit activities in order to bestow familiarity with them. This is also in accord with Jaworski's (2006) view of teaching as learning in practice or Llinares and Krainer's (2006) view that aspects of teaching are inextricably connected with learning. Jaworski (2006, p. 187) emphasises in particular that 'teaching develops through a learning process in which teachers and others grow into the practices in which they engage'. Conceiving teachers as learners has been neglected as 'we fight shy of using learning in relation to adults' (Lerman, 2001). The design of the intervention in this study sought to explicitly model to teachers (adults) as learners how they could enact in their own classrooms a neo-constructivist approach to mathematics teaching embodied in the RME model.

For example, the uptake of RME principles from a professional learning programme into classroom practice might become possible if the programme helps them modify their self-efficacy beliefs about their ability to enact the principles in their teaching through 'vicarious experiences and contextualised practice' (Posnanski, 2010) with those principles. Schoenfeld (2000) thus rightly attests that teacher knowledge leads to growth and change of teacher knowledge and hence to issues of teacher learning and professional development. Schoenfeld (2006, p. 485) reiterates that some of the most interesting approaches to professional development are those that take the notion of teacher learning seriously. The RME approach adopted in this study attests to the seriousness with which TPL was viewed.

\section{Criticisms of the RME approach}

However, note was made of the following criticisms of an RME approach directed to primary mathematics education as summarised by Van den Heuvel-Panhuizen (2010). Firstly, critics of RME argue that students do not get enough opportunity to practise, yet the emphasis in RME is practice with understanding and coherence, not isolated drill. Secondly, RME is accused of abolishing traditional digit-based algorithmic calculations in favour of new whole 
number-based written calculation. Thirdly, it is alleged that RME only involves word problems, yet these have always been an object of suspicion in RME. Finally, RME is accused of teaching students as many different calculation strategies as possible, which confuses them, yet it argues that students must have an understanding of the numbers with which they calculate and be able to use, if possible, shortened smart strategies. As a result of these criticisms the main didactical principles of RME which follow have been called 'didactical blunders' by opponents of RME.

\section{Principles of an RME pedagogy}

In the present study the workshop sessions for teachers were designed and conducted in accordance with Van den HeuvelPanhuizen's (2000, 2010) six principles underpinning RME pedagogy. I now briefly discuss these six principles.

\section{Activity principle}

This principle refers to the interpretation of mathematics as a human activity (Freudenthal, 1991) in which students are treated as active participants in the learning process. The transfer of ready-made mathematics directly to students is considered to be an 'anti-didactic inversion' (Freudenthal, $1973,1983,1991)$ that does not work (Van den HeuvelPanhuizen, 2010). Rather, students are confronted with problem situations so as to develop all sorts of mathematical tools and insights, formal or informal, by themselves (Cheung \& Huang, 2005). Amongst their 10 principles for effective professional development designed to improve the individual teacher's practice, Clarke and Clarke (2005) also recommend using teachers as participants in classroom activities to model desired classroom approaches so as to project a clearer vision of the proposed changes. As such in this study rather than being lectured to, participants were given activities (tasks) to work on by themselves. For example, in the module on symmetry and transformations participants were given materials (scissors, rulers, erasers, small frameless mirrors, $1 \mathrm{~cm}$ grid paper, coloured pencils or pen and pencil, drawing pins and matchboxes) and workbooks with classroom activities to work on.

\section{Reality principle}

The reality principle emphasises that RME is aimed at having students be capable of applying mathematics (Van den Heuvel-Panhuizen, 2010). Rather than commencing with certain abstractions or definitions to be applied later, students start with rich contexts demanding mathematical organisation, that is, contexts that afford horizontal and vertical mathematisation (Freudenthal, 1991). Thus, like many progressive approaches to mathematics education, RME strives to enable students to use or apply their mathematical understanding and tools to solve experientially real problems. Cooney (2001), for example, supports a realistic approach when asserting that activities in and of themselves are neither good nor bad; rather, it is the context that makes them effective. The course material in this study was designed in a manner that allowed participants to mathematise everyday experiences of transformations. For example, investigating reflectional and rotational symmetry in matchboxes, playing cards, spanners and nuts, clock faces, flowers and geometric transformations in Ndebele, Zulu, Xhosa and Zambian art. That is, there was a strong emphasis on students 'making sense' of the subject as also suggested by Hough and Steve (2007). See sample mathematical task items in Appendix 1.

\section{Level principle}

The level principle underlines that learning mathematics means that students pass through various levels of understanding (Van den Heuvel-Panhuizen, 2010). In other words, student activities should first start from the (informal) situation level closely bound to problem contexts so that domain-specific situational knowledge and strategies can be used (Cheung \& Huang, 2005). The second or referential level encompasses the use of concrete mathematical models representing mathematical objects. In Streefland and Freudenthal's formulations this is a level of 'model of' in reference to the concrete models' close connection to the situations described in the problem (Van den Heuvel-Panhuizen, 2003). The third or general level is a transitional level in which relationships are analysed through general mathematical models that can be dissociated from the problem contexts. In Streefland and Freudenthal's terminology such dissolute models are referred to as 'models for' where the focus is more on paradigmatic (or typical examples of) solution procedures that can be used to solve new problem situations (Van den Heuvel-Panhuizen, 2003). The fourth or formal level allows pure cognitive thinking or higher level of formal mathematical reasoning, reflection and appreciation (Cheung \& Huang, 2005).

One of the enduring strengths of the level principle, thus, is that it guides growth in mathematical understanding, from the concrete or enactive, to the iconic and, ultimately, to the symbolic representational forms espoused by Bruner (1960). Amongst the 10 principles for effective professional development that they cite, Clarke and Clarke (2005) assert the need to recognise that change is a gradual, difficult and often painful process. Thus, change or learning from one level of understanding to another requires scaffolding by more knowledgeable others or the sequencing of instruction in such a way that new learning carefully builds on previous knowledge. For example, the symmetry and transformation activities in this study did not end with concrete models, but extended to triangles, quadrilaterals, irregular shapes, calculations or determinations of axes of reflectional symmetry, angles and orders of rotational symmetry and even the use of congruency and similarity to prove simple circle geometry theorems thus signifying some progression from everyday experiences to 'models of' (horizontal mathematisation) to 'models for' and to higher levels of mathematical reasoning or proof (vertical mathematisation).

\section{Intertwinement principle}

This principle means that mathematical domains such as number, measurement and data handling are not considered 
as isolated curriculum chapters but as heavily integrated (Van den Heuvel-Panhuizen, 2010). Students are given tasks involving rich problems in which they can use various mathematical tools and knowledge both within and across topics in a subject. This principle aligns with Shulman's (1986) knowledge of the curriculum (KC). For example, in this study geometrical transformations (rotations, reflections and enlargements) were integrated with analytic geometry when coordinates were involved and were also linked to cases of triangle congruency and to circle geometry to solve simple riders as alluded to earlier. A major strength of the intertwinement principle is that it engenders a more coherent experience of the mathematics curriculum.

\section{Interactivity principle}

This principle signifies that the learning of mathematics is not only a personal activity but also a social activity (Van den Heuvel-Panhuizen, 2010). To that end, learners should be afforded opportunities to share their strategies and inventions with each other. By discussing each other's findings, students can get ideas for improving their strategies (Van den Heuvel-Panhuizen, 2000). For the simple reason that the whole class approach has been the hallmark of traditional methods, in this study I privileged collaborative group work to emphasise to teachers how it could solve problems often experienced in overcrowded classrooms. Included amongst Clarke and Clarke's (2005) 10 principles for effective professional development is the logic to afford teachers opportunities for support from peers and critical friends and to discuss problems and solutions of learning difficulties as a group. Moreover, interaction can evoke both individual and collective reflection, which can scaffold students to higher levels of mathematical understanding. In concurrence, Krainer (2002, p. 283, as cited by Roesken, 2011) asserts that an increased competence in reflection raises the quality of action and the knowledge of views of others enlarges the view of one's own situation.

\section{Guidance principle}

This principle means that students are provided with a 'guided' opportunity to 'reinvent' mathematics by 'striking a delicate balance between the force of teaching and the freedom of learning' (Freudenthal, 1991, p. 55). This implies that in RME pedagogy teachers are expected to play a proactive role in students' learning and that educational programmes should contain scenarios that have the potential to work as levers to reach shifts in students' understanding (Van den Heuvel-Panhuizen, 2010). In this study the delivery mode privileged a problem-based learning approach in which the instructional materials guided the participants to work in small groups but were also individually accountable for the completion of their own homework tasks. The assessment tasks were incorporated to ensure that teachers developed what Adler (2005) refers to as mathematics (knowledge) for teaching. The facilitator encouraged participants to seek assistance from colleagues first and foremost and consult the facilitator as a last resort. The facilitator remained available all the time to anticipate participants' difficulties and to help groups in meaning negotiation and collective self-reflection on the effectiveness of their problem-solving strategies. The significance of the guidance principle is that teachers must be able to foresee where and how they can anticipate the students' understandings and skills that are just coming into view in the distance (Van den Heuvel-Panhuizen, 2003).

The didactic approach to be used for the sessions was explained to the teachers in advance and teachers were encouraged to identify its strengths and challenges. With that understanding, the following research questions guided the study:

1. What were the Senior Phase mathematics teachers' reactions to the usefulness of the RME-based TPL programme?

2. How did the participants perform in an achievement test at the end of the topic on transformations?

\section{Research methodology Research approach}

A concurrent mixed-methods approach was adopted using a semi-structured questionnaire with both closed and openended items and an achievement test with assorted items on transformations. The research design took the form of a survey and an achievement test to elicit the quickest responses with the least strain on teachers and yet be informative enough for subsequent sessions later in the year.

\section{The sample for this study}

A convenience sample of 47 (out of 53) Senior Phase mathematics teachers that participated in the workshop sessions responded to the feedback questionnaire. Table 1 shows the demographic information relating to the teachers. From Table 1 it is observable that the majority of the teachers (57\%) were teaching Senior Phase mathematics (Grades 7, 8 and 9). Just over a third (38\%) taught both the Senior Phase classes and Further Education and Training (Grades 10-12) classes. Furthermore, the majority of teachers (51\%) had at least 10 years of teaching experience. At least $45 \%$ of the teachers had an Advanced Certificate in Education (ACE) or higher and the majority (57\%) of the teachers were female. Eight teachers left their highest professional qualifications column blank, which could indicate some sensitivity about disclosing qualifications.

Fifty out of 53 teachers took the achievement test on transformations at the end of the TPL sessions.

\section{Instruments}

The main instruments for the study were:

- A questionnaire consisting of eight Likert-type items intended to elicit answers from both closed and openended questions and an open-ended item (see Figure 1).

- An achievement test at the end of the two-week TPL sessions during which the topic was presented. 
TABLE 1: Demographic data.

\begin{tabular}{|c|c|}
\hline Variable & No. of teachers \\
\hline \multicolumn{2}{|l|}{ Gender } \\
\hline Female & 27 \\
\hline Male & 19 \\
\hline Blank & 1 \\
\hline \multicolumn{2}{|l|}{ Age } \\
\hline$<30$ & 7 \\
\hline $30-39$ & 11 \\
\hline $40-49$ & 14 \\
\hline $50-59$ & 7 \\
\hline$\geq 60$ & 2 \\
\hline Blank & 6 \\
\hline \multicolumn{2}{|c|}{ Teaching experience } \\
\hline$<5$ years & 8 \\
\hline $5-9$ years & 9 \\
\hline 10-14 years & 4 \\
\hline $15-19$ years & 6 \\
\hline 20-24 years & 4 \\
\hline $25-29$ years & 5 \\
\hline$\geq 30$ & 5 \\
\hline Blank & 6 \\
\hline \multicolumn{2}{|c|}{ Highest grade taught } \\
\hline 7 & 1 \\
\hline 8 & 7 \\
\hline 9 & 19 \\
\hline 10 & 13 \\
\hline 11 & 3 \\
\hline 12 & 2 \\
\hline Blank & 2 \\
\hline \multicolumn{2}{|c|}{ Highest professional qualification } \\
\hline PDE & 3 \\
\hline HDE & 3 \\
\hline NPDE & 1 \\
\hline Dip. Ed. & 3 \\
\hline ACE & 4 \\
\hline Degree & 12 \\
\hline PGCE/Hons & 5 \\
\hline Blank & 13 \\
\hline
\end{tabular}

PDE, Primary Diploma in Education; HDE, Higher Diploma in Education; NPDE, Nationa Professional Diploma in Education; Dip. Ed., Diploma of Education; ACE, Advanced Certificate in Education; PCGE, Postgraduate Certificate in Education; Hons, Honours.

\section{Results}

\section{Quantitative results of the questionnaire}

Table 2 shows the numerical results of the questionnaire for the eight closed-ended question parts. On the whole there appeared to be an overwhelming consensus about the suitability of the content, activities, didactical approaches and the teaching materials, with the exception of whether the mathematical tasks were challenging enough.

The results show that most of the items or principles received approval as having been in evidence in the presentations of geometrical transformations. The Cronbach's alpha reliabilities for all item deletions all fell within an acceptable range of between 0.7 and 0.8 , including the overall value. Two items, in respect of the level and the guidance principles, had Cronbach's alpha values higher than the overall value, suggesting that their deletion would improve the reliability of the scale. However, the differences were not statistically different so the items were maintained for completeness of the reporting.

\section{Quantitative results of the achievement test}

Table 3 shows how teachers performed in the various categories of transformation concepts. The symmetry of quadrilaterals was best understood whilst the symmetries of irregular shapes (in sample task item 2, see Appendix 1) were the least understood. The main problem from these items was that many teachers would determine only a limited number of lines of symmetry where reflectional symmetry was concerned. The order of rotational symmetry was a challenge to some students where rotational symmetry was concerned. Furthermore, where both rotational and reflectional symmetry co-existed it was difficult for some teachers to recognise both. The second most misunderstood concept or process was the construction of a triangle and a parallelogram (plane shapes).

Figure 2 is a box-and-whisker plot obtained from IMathAS. com's Boxplot Grapher (http://www.imathas.com/ stattools/boxplot.html) showing the overall performance of the 50 teachers who wrote the test.

The five-number summary of the distribution was: a minimum mark of $40 \%$, a lower quartile mark of $63 \%$, a median mark of $74.5 \%$ (compared to a mean mark of $72.1 \%$, meaning scores were skewed to the left by -0.412), an upper quartile mark of $82 \%$ and a maximum mark of $96 \%$. The distribution had a standard deviation of 13.34 and a standard error of 1.887 . The mean was still lower than would be expected of teachers teaching these concepts but the variance was understandable given that some teachers were not necessarily qualified to teach mathematics.

\section{Qualitative results Relevance of tasks to the reality principle}

Some responses gave evidence of awareness of the importance of linking mathematics to the everyday life experiences of learners (reality principle, as exemplified in sample task item 1 in Appendix 1), as the following examples show:

Teacher 13: Especially for the FET Phase where learners do not have a grasp of linking it into everyday life.

Teacher 15: Very good examples, the examples is very practical and relates to real-life situations.

Teacher 42: They were challenging, especially with transformation you ended up taking a tracing paper so that you can make sure if your transformation is correct.

\section{Relevance of tasks to the level principle}

Whereas some participants felt the tasks were easy, others felt that they were challenging or at least would be challenging enough for their learners. Tasks that are challenging should scaffold learners to move from one level of understanding to the next (level principle, as exemplified in task item 2 


\begin{tabular}{|c|c|c|c|c|c|c|}
\hline \multicolumn{7}{|c|}{$\begin{array}{l}\text { Instructions to participants } \\
\text { Indicate how strongly you judge the following aspects of presentations on transformation geometry met your expectations by choosing from the following: } \\
\text { 1: Strongly disagree, } 2 \text {. Disagree, } 3 \text {. Undecided, } 4 \text {. Agree, } 5 \text {. Strongly agree } \\
\text { Explain your answer in the space provided below each question. }\end{array}$} \\
\hline \multirow[t]{9}{*}{5} & 4 & 3 & 2 & 1 & The presentations on geometrical transformations were adequate in respect of: & \\
\hline & & & & & $\begin{array}{l}\text { Real-life uses of transformation geometry (reality principle) } \\
\text { Explain.................................................................... }\end{array}$ & 1 \\
\hline & & & & & $\begin{array}{l}\text { My active participation as an individual (activity principle) } \\
\text { Explain:................................................................... }\end{array}$ & 2 \\
\hline & & & & & $\begin{array}{l}\text { Challenging tasks (level principle). } \\
\text { Explain:........................................ }\end{array}$ & 3 \\
\hline & & & & & $\begin{array}{l}\text { Connections with other topics (intertwinement principle) } \\
\text { Explain:............................................................................ }\end{array}$ & 4 \\
\hline & & & & & 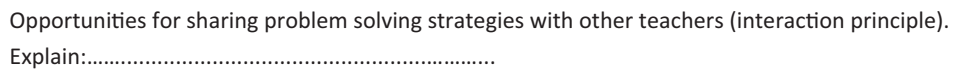 & 5 \\
\hline & & & & & $\begin{array}{l}\text { Guidance from the tasks and the presenter (guidance principle). } \\
\text { Explain: }\end{array}$ & 6 \\
\hline & & & & & $\begin{array}{l}\text { Relevance of content to the CAPS for Grades 7-9 } \\
\text { Explain: }\end{array}$ & 7 \\
\hline & & & & & $\begin{array}{l}\text { Relevance and adequacy of the teaching and learning materials } \\
\text { Explain: }\end{array}$ & 8 \\
\hline \multicolumn{7}{|c|}{ Suggestions for future improvement: } \\
\hline
\end{tabular}

FIGURE 1: Feedback questionnaire.

TABLE 2: Item total statistics.

\begin{tabular}{|c|c|c|c|c|c|c|c|c|}
\hline \multirow[t]{2}{*}{ Item no. } & \multirow[t]{2}{*}{ Short description } & \multicolumn{5}{|c|}{$\%$ agreement } & \multirow[t]{2}{*}{ Corrected item-total correlation } & \multirow[t]{2}{*}{ Cronbach's alpha if item deleted } \\
\hline & & SD & D & u & A & SA & & \\
\hline 1 & Reality principle & - & - & - & 66 & 34 & 0.712 & 0.701 \\
\hline 3 & Level principle & - & - & 2 & 79 & 19 & 0.475 & 0.777 \\
\hline 4 & Intertwinement principle & 4 & 15 & 2 & 40 & 39 & 0.537 & 0.728 \\
\hline 5 & Interaction principle & - & 2 & 2 & 60 & 36 & 0.347 & 0.751 \\
\hline 6 & Guidance principle & - & 2 & 2 & 81 & 15 & 0.263 & 0.761 \\
\hline 7 & Relevance to CAPS & - & 2 & 2 & 66 & 30 & 0.500 & 0.726 \\
\hline 8 & Teaching materials & - & 2 & 2 & 68 & 28 & 0.568 & 0.714 \\
\hline
\end{tabular}

SD, Strongly disagree; D, Disagree; U, Undecided; A, Agree; SA = Strongly agree.

For all items Cronbach's alpha $=0.758$; Standard deviation $=3.161$.

TABLE 3: Distribution of marks per sub-topic.

\begin{tabular}{|c|c|c|c|c|c|c|}
\hline Transformation concept & $\begin{array}{l}\text { Symmetries of } \\
\text { quadrilaterals }\end{array}$ & $\begin{array}{c}\text { Symmetries of } \\
\text { irregulars }\end{array}$ & $\begin{array}{c}\text { Transformation } \\
\text { rules } \\
\end{array}$ & $\begin{array}{c}\text { Rotations of } \\
90 \text { degrees }\end{array}$ & $\begin{array}{c}\text { Construction of } \\
\text { plane shapes }\end{array}$ & $\begin{array}{c}\text { Congruency and its } \\
\text { applications }\end{array}$ \\
\hline Possible mark & 11 & 9 & 9 & 7 & 7 & 7 \\
\hline Mean mark achieved & 9.4 & 4.5 & 7.4 & 6.3 & 4.8 & 5.0 \\
\hline$\%$ achievement & $86 \%$ & $50 \%$ & $82 \%$ & $89 \%$ & $70 \%$ & $72 \%$ \\
\hline Not achieved & 1.6 & 4.5 & 0.2 & 0.7 & 0.2 & 2.0 \\
\hline
\end{tabular}

in Appendix 1); they need not be too difficult. The following example responses attested to the level principle:

Teacher 1: It start with self-discovery and it end with problems of a 'higher order' level. It allows critical thinking. There were some stage that I felt so 'stupid' but eventually I got it right. Specifically the reflection in $y=-x$ and $y=x$ and the rotation.
Teacher 23: Plus or minus $20 \%$ challenging. But I am currently teaching Grade 9 and 10 maths (for 32 years!!). The ones I found challenging were module 30 : rotations and enlargement; similarity activities.

Teacher 45: It took a lot of different cognitive skills. e.g. When you have to do the rotation of $180^{\circ}$ clockwise and anticlockwise. 


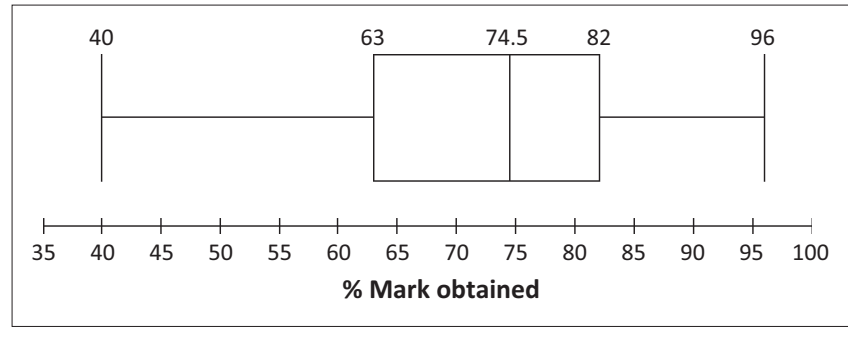

FIGURE 2: Box-and-whisker plot of the overall performance.

\section{Relevance of tasks to the activity principle}

The level of participation by participants as individuals (activity principle) as well as in small groups (interaction principle) was perceived as in the following sample responses:

Teacher 15: I took active part as an individual in my group, I had some particular time where I was explaining to my colleagues. This took part for the whole group where one member would be explaining to us where we were not understanding.

Teacher 9: I found the answers first then consulted.

Teacher 37: As an individual I have to draw making the diagrams, answers then as a group we make comparisons of our answers.

\section{Relevance of tasks to the interaction principle}

The importance of the interaction principle at work was illustrated by the following responses, amongst others, which show how collaborative work helped the participants overcome their challenges:

Teacher 8: At times I differed with group members about some answers. We explained to each other and learned from each other.

Teacher 10: I as a teacher struggle with some of the concepts and the team mates and facilitator made it clear to me. Thanks!

Teacher 13: Although we spoke different home languages and Afrikaans is my mother tongue my peers helped me by explaining the meaning of difficult words and concepts and formulas.

\section{Relevance of tasks to the guidance principle}

Although most of the guidance principle was built into the materials and the overall approach, some of it was evident in the following sentiments:

Teacher 23: I have picked up/been exposed to a lot of new ideas how to present my lessons, especially on Grade 9 and 10 level. Be more practical in the class! More constructions. My own worksheets in class must be clear and well planned.

Teacher 30: If something wasn't so clear to us we consulted each other in groups or with the facilitator.

Teacher 39: The material can also be used in the classroom for own lessons as it contains adequate scaffolding.

\section{Relevance of geometrical content on transformations to the Senior Phase}

The overwhelming majority of the teachers who attested to the relevance of the topic content to the Senior Phase described such relevance in varied ways, as the following examples show:

Teacher 19: It includes topics outlined in the work schedule and it had many activities which will assist learners in problem solving.

Teacher 23: It was relevant because it is on the syllabus of Grade 8 and 9 . It also emphasises the starting point for this topic.

Teacher 34: It is relevant in the Senior Phase but looking at the FET (Grades 10, 11 and 12) Maths the transformation is no longer done in CAPS.

\section{Relevance and adequacy of teaching and learning materials used}

The majority of participants reported that the materials they used were adequate for the tasks and some declared their readiness to adopt some of the activities and materials used:

Teacher 17: Everything we needed to use was available to us. The tracing paper were available to do the construction, instrument box to draw circle and triangle.

Teacher 4: The problem we encounter in our school have large numbers and we don't have some of the equipment to demonstrate these types of transformations (e.g. mirrors) line of symmetry same as with patterns. I learnt a lot from this class because everything was demonstrated to us.

Teacher 8: It was adequate and appropriate because the chapter of transformation were covered and we had all the material needed to complete the activities. The material needed are things you have in your class.

Baturo, Cooper, Doyle and Grant (2007) argue that effective teacher education tasks should enable translation to classrooms (at the technical level), enhance the success of student learning (at the domain level) and facilitate transfer to other topics (at the generic level). The latter level coincides with the intertwinement principle, which was largely built into the materials.

\section{Suggested improvements in future sessions}

Many participants felt that the time allocated for the topics covered was inadequate. An almost equal number apiece were (1) happy with the delivery mode as it was, (2) needed more whole class facilitator explanations and discussions or (3) would have preferred their home language (predominantly Afrikaans) to be used for instruction and materials. Some even felt they were competent enough to be engaged as facilitators. The examples below show some typical recommendations:

Teacher 39: We need more time ... was squashed!!! I was not able to complete the activities of any day except for the last day (Friday) (That was when I concentrated mostly on myself.) This was not good in my opinion as we were at the course to SHARE and ENRICH each other.

Teacher 8: I am happy with the workshop as it is. Such workshops are good for us. You also need to do them even for Grade 11 and 12 as well in future. Topic we can be covered again in Grade 9 is finance and conversion table (metric + imperial). 
Teacher 40: Well only worked small group; but maybe there could have even more of a plenary where we could hear from the class as a whole.

Teacher 11: Notes in Afrikaans will be much appreciated. You can go through us with the answers. More explaining. Teachers forget things

Teacher 3: Would enjoy being part of your presenters team - I am a $100 \%$ educator.

\section{Discussion}

Whilst the quantitative results showed an approval of the RME-based teacher professional learning opportunity the teachers received, the qualitative aspects of the data gave some details about the specific instances in which the teachers perceived the contact session to have fulfilled their expectations at Guskey's Level 1 of professional learning effectiveness. All the main principles of RME were in evidence in the teachers' feedback with the exception of the intertwinement principle, which was largely built into the materials. The participants overwhelmingly felt that they were actively engaged both as individuals (activity principle) and as small groups (interaction principle). They also felt that the activities were based on real-life experiences that could be of interest to their learners (reality principle) and challenging enough to their learners and to some of the participants (level principle). They felt that the materials used helped them to understand the geometry of transformations much better and they thought that they received enough guidance from the curriculum materials used (guidance principle). However, they felt that there could have been more whole-class discussions to tie up the loose ends. This was not surprising for teachers who came from a background of traditional teacher-centred approaches that still dominate the overcrowded, under-resourced mathematics classrooms in disadvantaged communities.

In line with their varied levels of experience and expertise, the teachers varied widely in their levels of mathematical self-efficacy, some feeling overwhelmed because of teaching the subject for the first time or inadequately supplied with curriculum materials whilst a few others felt on top of the game and wished they could be involved as resource persons. That was an exciting prospect, which should open up the possibility of transformative models for use in sustained, collaborative, professional development (Johnson \& Marx, 2009). The teachers performed modestly on the achievement test, showing some learning gains at Guskey's Level 2 as well. The varied levels of understanding were however shown by the analysis of variance statistics, which also confirmed the varied levels of experience and expertise in mathematics teaching at the Senior Phase level. Surprisingly, some teachers did not even know where they could obtain topic-relevant materials such as tracing paper in order to make the teaching of transformations more hands-on, especially rotations, enlargements and reflections that are not along the $x$-axis and $y$-axis, which seemed to challenge some participants.

Lessons drawn from the workshop activities were principally that tasks should revolve around learners' experiential world in order to be of interest and relevance to them (reality principle). There was considerable positive attitude expressed towards activity-based learning (activity principle) and collaborative learning (interaction principle). TPL programmes should thus relentlessly model the teaching strategies intended for teachers to adopt in their classrooms. As Windschitl (2002) observes, many teachers cannot implement constructivist ways of teaching mainly because they have not experienced them themselves either during their own schooling or their own initial training.

\section{Conclusion}

The purpose of this study was to investigate in-service teachers' perceptions of the relevance of a teacher professional learning programme modelled on RME principles. A major positive outcome of the study was that many teachers felt better prepared to adopt some activity-oriented tasks in their classrooms in the teaching of not only transformations but geometry and mathematics in general. Unless teachers can commit themselves to instituting change in the ways they teach the subject in their classrooms little change can come about. Given the endemic shortage of qualified mathematics teachers, it is not surprising that many teachers of mathematics are not specialist mathematics teachers especially in the Senior Phase and thus require constant support. Of interest too was the fact that teachers are sometimes alert to syllabus changes that bring about discontinuity in mathematical content that is taught in different phases of the schooling system. The recent removal of transformation geometry from the Curriculum and Assessment Policy Statements for the Further Education and Training Phase (Grades 10-12) has caused some teachers to question the future relevance of the topic to the Senior Phase. 'If it is not going to be examined later at the National Senior Certificate, why bother?' seems to be a rational question in a system increasingly driven by high stakes examinations. These are questions that curriculum planners have to ponder to convince teachers about the wisdom of including topics that the latter have historically not been comfortable with in the first instance.

Finally, the fact that teachers in this study engaged with mathematical content meaningfully helped to address some of their classroom mathematical knowledge needs. Although a few still scored marks below $50 \%$ the average mark of $72 \%$ was presumably modest enough to inspire confidence in their feelings of self-efficacy in transformation geometry (Guskey's Levels 1 and 2). Further follow-up research is needed to explore the impact of the TPL programme on organisational teacher support (Guskey's Level 3), implementation support and monitoring (Guskey's Level 4) and ultimately on student learning outcomes (Guskey's Level 5).

\section{Limitations of the study}

This study was limited to teachers' perceptions of the effectiveness of a contact session of a teacher professional learning programme based on RME principles and scores obtained in an achievement test. It therefore does not cover 
the full spectrum of the entire lifespan of the programme which included class visits and another contact session later in the same year.

\section{Ethical considerations}

Permission was granted by the Western Cape Education Department to conduct this study and ethical clearance was obtained from Stellenbosch University's Research Ethics Committee. The participants in this study signed letters of consent and were advised of the objectives for the research, which primarily sought to improve future in-service training. The participants were assured of confidentially and anonymity. Their names were neither required in their questionnaire responses nor were they going to be used in the analysis of the achievement test results.

\section{Acknowledgements}

I acknowledge that my involvement in this study was part of my research duties at the Stellenbosch University Centre for Pedagogy (SUNCEP). I am also grateful to my colleagues, Ramesh Jeram (for allocating me the responsibility of the geometry modules covered in this study) and Cosmas Tambara (for helping me in the administration of the questionnaire).

\section{Competing interests}

I declare that I have no financial or personal relationship(s) that might have inappropriately influenced me in writing this article.

\section{References}

Adler, J. (2005). Mathematics for teaching: What is it and why is it important that we talk about it? Pythagoras, 62, 2-11. http://dx.doi.org/10.4102/pythagoras.v0i62.109

Baturo, A., Cooper, T., Doyle, K., \& Grant, E. (2007). Using three levels in design of effective teacher-education tasks: The case of promoting conflicts with intuitive understandings in probability. Journal of Mathematics Teacher Education, 10, 251-259. http://dx.doi.org/10.1007/s10857-007-9042-z

Beck, J., Czemiak, C., \& Lumpe, A. (2000). An exploratory study of teachers' beliefs regarding the implementation of constuctivism in their classrooms. Journal of Science Teacher Education, 11, 323-343.

Bruner, J. (1960). The process of education. Cambridge, MA: Harvard University Press.

Cheung, K.C., \& Huang, R.J. (2005, May). Contribution of Realistic mathematics Education and Theory of Multiple Intelligences to mathematics practical and integrated applications: Experiences from Shanghai and Macao in China. Paper presented at the 15th International Commission of Mathematics Instruction Study Conference. Available from http://www.mathunion.org/fileadmin/ICMI/files/ Conferences/ICMI_studies/Study15/Cheung_KC_ICMI15_prop.doc

Clarke, D., \& Clarke, B. (2005, May). Effective professional development for teachers of mathematics: Key principles from research and program embodying these principles. Paper presented at the 15th International Commission of Mathematics Instruction Study Conference. Available from http://www.mathunion.org/fileadmin/ICMI/files/ Conferences/ICMI_studies/Study15/Cheung_KC_ICMI15_prop.doc

Clarke, D., \& Hollingsworth, H. (2002). Elaborating model of teacher professional growth. Teaching and Teacher Education, 18, 947-967. http://dx.doi.org/10.1016/ S0742-051X(02)00053-7

Cooney, T.J. (2001). Considering the paradoxes, perils and purposes for conceptualizing teacher development. In F.L. Lin, \& T.J. Cooney (Eds.), Making conceptualizing teacher development. In F.L. Lin, \& T.J. Cooney (Eds.), Making
sense of mathematics teacher education (pp. 9-31). Dordrecht: Kluwer. http:// sense of mathematics teacher education
dx.doi.org/10.1007/978-94-010-0828-0_1

Day, C. (1999). Professional development and reflective practice: purposes, processes and partnerships. Pedagogy, Culture and Society, 7(2), 221-233. http://dx.doi. and partnerships. Pedagogy, Culture
org/10.1080/14681369900200057

Department of Basic Education. (2012). Report of the Annual National Assessments 2012: Grades 1 to 6 \& 9. Pretoria: DBE.
Dickinson, P., \& Hough, S. (2012). Using realistic mathematics education in UK classrooms. Manchester: Paul Dickinson and Sue Hough. Available from http:// www.mei.org.uk/files/pdf/rme_impact_booklet.pdf

Freudenthal, H. (1973). Mathematics as an educational task. Dordrecht: Riedel Publishing Company.

Freudenthal, H. (1977). Antwoord door Prof. Dr H. Freudenthal na het verlenen van het eredoctoraat [Answer by Prof. $\mathrm{Dr} \mathrm{H}$. Freudenthal upon being granted an honorary doctorate]. Euclides, 52, 336-338.

Freudenthal, H. (1983). Didactical phenomenology of mathematical structures. Dordrecht: Riedel Publishing Company.

Freudenthal, H. (1991). Revisiting mathematics education. China lectures. Dordrecht: Kluwer Academic Publishers.

Goodall, J., Day, C., Lindsay, G., Muijs, D., \& Harris, A. (2005). Evaluating the impact of continuing professional development. Warwick: University of Warwick.

Guskey, T. (2000). Evaluating professional development. Thousand Oaks, CA: Corwin Press.

Guskey, T.R. (2002). Professional development and teacher change. Teachers and Teaching: Theory and Practice, 8(3), 381-391. http://dx.doi.org/10.1080/ 135406002100000512

Hadi, S. (2002). Effective teacher professional development for the implementation of realistic mathematics education in Indonesia. Twente: University of Twente.

Hellmig, L. (2009, January-February). Effective blended professional development for teachers of mathematics: Design and evaluation of the 'UPOLA' program. Paper presented at the Sixth Congress of the European Society for Research in Mathematics Education, Lyon.

Hough, S., \& Steve, G. (2007). Realistic mathematics education. Derby: Association of Teachers of Mathematics.

Jaworski, B. (2006). Theory and practice in mathematics teaching development: Critical inquiry as a mode of learning in teaching. Journal of Mathematics Teacher Education, 9, 187-211. http://dx.doi.org/10.1007/s10857-005-1223-z

Johnson, C.C., \& Marx, S. (2009). Transformative professional development: A model for urban science education reform. Journal of Science Teacher Education, 20, 113-134. http://dx.doi.org/10.1007/s10972-009-9127-x

Lerman, S. (2001). Cultural and discursive psychology: A sociocultural approach to studying the teaching and learning of mathematics. Educational Studies in Mathematics, 46, 87-113. http://dx.doi.org/10.1023/A:1014031004832

Linares, S., \& Krainer, K. (2006). Mathemaics (student) teachers and teachers educators as learners. In A. Gutierrez, \& P. Boero (Eds.), Handbook of research on the psychology of mathematics education: Past, present and future (pp. 429-459). Rotterdam: Sense Publishers.

Posnanski, T.J. (2010). Developing understanding of the nature of science with in a professional development program for inservice elementary teachers: Project nature of elementary science teaching. Journal of Science Teacher Education, 21 589-621. http://dx.doi.org/10.1007/s10972-009-9145-8

Roesken, B. (2011). Hidden dimensions in the professional development of mathematics teachers: In-service education for and with teachers. Rotterdam: Sense Publishers. http://dx.doi.org/10.1007/978-94-6091-433-1

Romberg, T.A. (2001). Mathematics in context. Chicago, IL: Education Development Center, Inc.

Schoenfeld, A.H. (2000) Purposes and methods of research in mathematics education Notices of the American Mathematical Society, 47(6), 2-10.

Schoenfeld, A.H. (2006). Mathematics teaching and learning. In P.A. Alexander, \& P.H. Winne (Eds.), Handbook of educational psychology (2nd edn.) (pp. 479-510). Mahwah, NJ: Erlbaum

Shulman, L.S. (1986). Those who understand: Knowledge growth in teaching. Educational Researcher, 15(2), 4-14. http://dx.doi.org/10.3102/0013189x015002004

Sowder, J. (2007). The mathematical education and development of teachers. In F.K. Lester (Ed.), Second handbook of research on mathematics teaching and learning (pp. 157-224). Charlotte, NC: Information Age.

Treffers, A. (1987). Three dimensions, A Model of goal and theory description in mathematics instruction - The Wiscobus Project. Dordrecht: Reidel Publishing Company.

Van den Heuvel-Panhuizen, M. (2000). Mathematics education in the Netherlands: A guided tour. Freudenthal Institute CD-ROM for ICME9. Utrecht: Utrecht University. Available from http://www.fisme.science.uu.nl/staff/marjah/documents/TOURdef+ref.pdf

Van den Heuvel-Panhuizen, M. (2003). The didactical use of models in realistic mathematics education: An example from a longitudinal trajectory on percentage. Educational Studies in Mathematics, 54, 9-35. http://dx.doi.org/10.1023/ B:EDUC.0000005212.03219.dc

Van den Heuvel-Panhuizen, M. (2010). Reform under attack - Forty years of working on better mathematics education thrown on the scrapheap? No way! In L. Sparrow, B. Kissane, \& C. Hurst (Eds.), Shaping the future of mathematics education: Proceedings of the 33rd annual conference of the Mathematics Research Group of Australasia (pp. 1-25). Fremantle: MERGA. Available from http://www.merga. net.au/publications/counter.php?pub=pub_conf\&id=863

Windschitl, M. (2002). Framing constructivism in pracatice as the negotiation of dilemmas: An analysis of the conceptual, pedagogical, cultural, and political challenges facing teachers. Review of Educational Research, 72(2), 131-175. http://dx.doi.org/10.3102/00346543072002131 


\section{Appendix 1}

\section{Sample worksheet tasks}

1. Sometimes there are good and practical reasons to make an object symmetrical.

a) What type of symmetries do you find in each of the following four playing cards: 8 of clubs, 10 of diamonds, Queen of spades, and King of hearts.
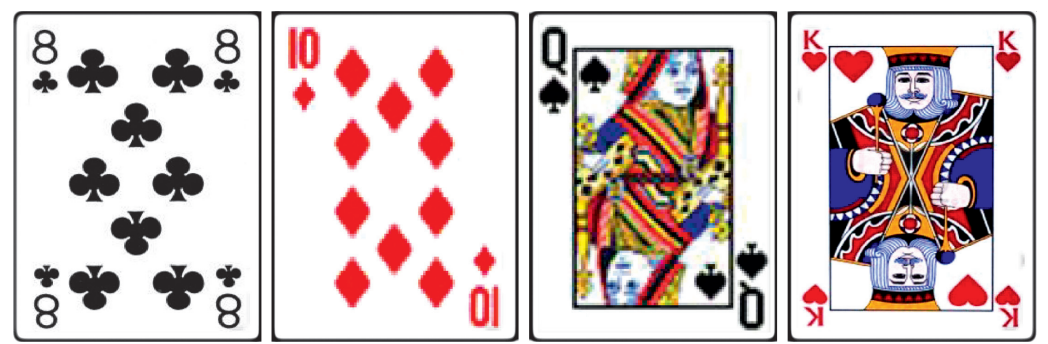

b) Why is it convenient when a playing card is symmetrical?

c) What sort of symmetries occur in this nut and spanners?
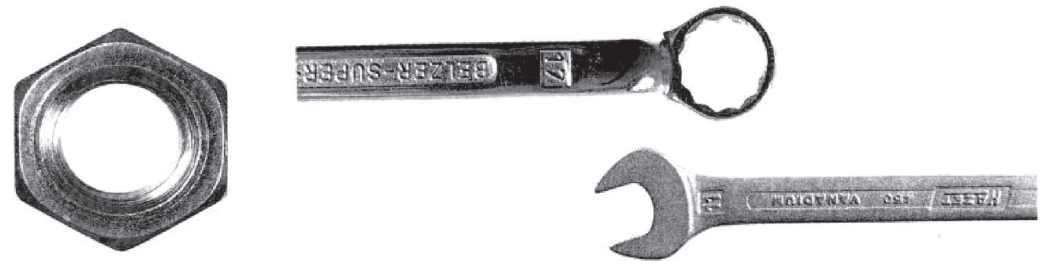

3. Investigate each of the figures below for line (reflectional) or rotational symmetry by showing the following, where applicable (for line symmetry check your answer by folding or using the provided mirror, for rotational symmetry use the tracing paper provided):

i) line axis (or axes) of symmetry,

ii) the centre point of rotation

iii) the angle of rotational symmetry,

iv) the order of symmetry.

a
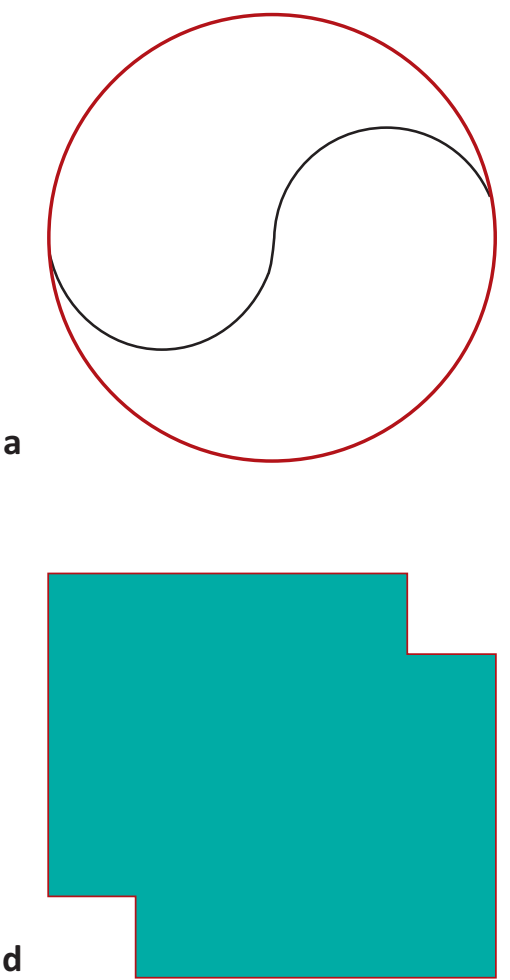

b

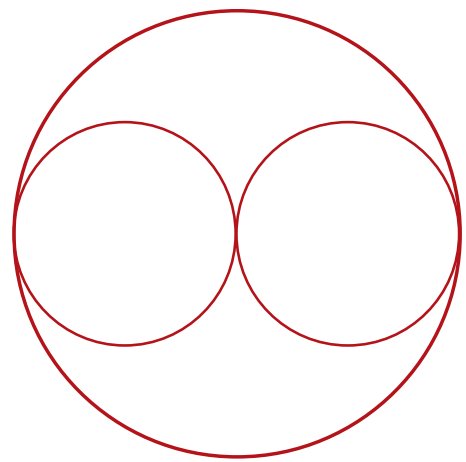

e
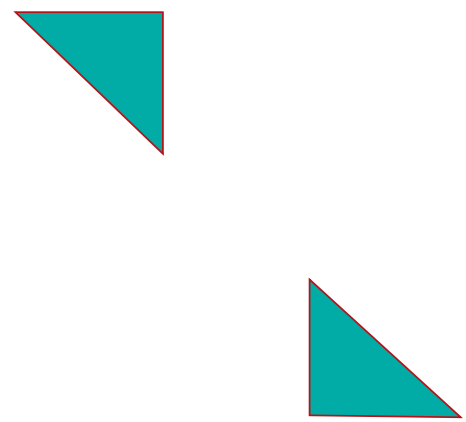

c
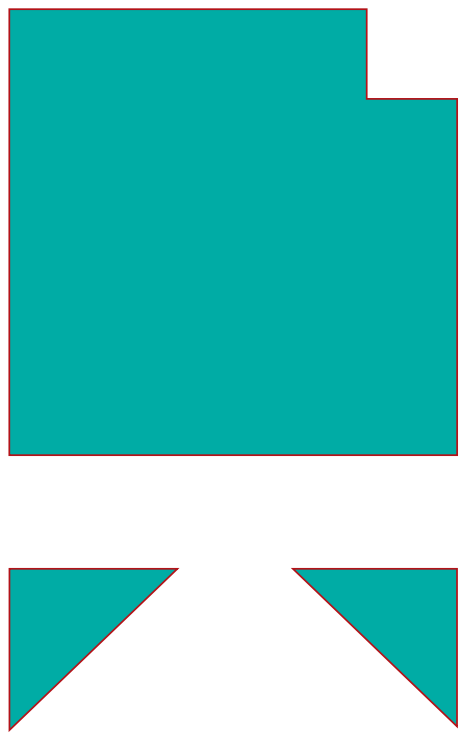

f
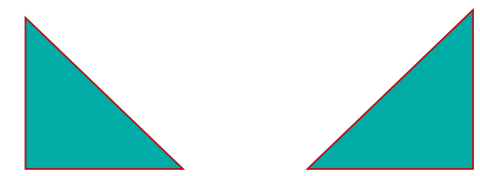